\title{
Social Nutrition and Prohibiting Famine
}

By Alex de Waal

The world almost conquered famine. By the first decade of this century, we were at the threshold of abolishing this age-old scourge, for good. But in the last two years we have slipped back. Not only has the threat of famine returned-most notably to Yemen-but we are witnessing an unprincipled and dishonest assault on the norms and practices of progressive international humanitarianism, which could return us to a darker era of widespread starvation.

Some nutritionists have seen their calling as social and political activists, as well as biomedical specialists. Forty years ago, the pioneers of nutritional programmes in food emergencies, John Rivers and his colleagues, identified the thresholds whereby extreme poverty became famine-as freezing water changes its state into ice-in both socio-economic and medical terms. ${ }^{1}$ Arnold Pacey and Philip Payne ${ }^{2}$ argued that reducing malnutrition in developing countries demanded socially progressive forms of rural development. More recently, Susanne Jaspars and Helen Young ${ }^{3}$ have placed the challenge of emergency nutrition squarely within the socio-economic and political vortex of factors that lead to humanitarian crises.

Such a social nutrition agenda is more relevant than ever today.

In the last half century, the death toll in famines globally has plummeted, to barely five percent of the numbers recorded beforehand. ${ }^{4}$ Improved humanitarian technical capacity has much to do with this. Today, improved water and sanitation,

\footnotetext{
${ }^{1}$ Rivers, J., Holt, J., Seaman, J. and Bowden, M. (1976) 'Lessons for epidemiology from the Ethiopian famines', Annales Société Belge de Médecine Tropicale, 56, 345-57.

2 Pacey, A. and Payne, P. (1985) Agricultural Development and Nutrition, London: Hutchinson and Co. by arrangement with the FAO and UNICEF.

3 Young, H., and Jaspars, S. (2009) 'Review of Nutrition and Mortality Indicators for the Integrated Food Security Phase Classification (IPC): Reference Levels and Decision-making', New York, United Nations Standing Committee on Nutrition, Task Force on Assessment, Monitoring and Evaluation.

${ }^{4}$ Alex de Waal (2018) Mass Starvation: The history and future of famine, Cambridge, Polity.
} 
better public health, and more effective treatment of acute malnutrition, means that mortality rates in refugee camps are far lower than they were thirty or forty years ago. Humanitarian programmes are mounted in places, such as war zones, where relief agencies never used to venture. There is tremendous empirical evidence to show that humanitarian action works: it is the right thing to do for both ethical and practical reasons.

We have made less progress in tackling the political causes of famine. Indeed, while the climatic and economic causes of extreme hunger have been massively reduced, humanitarian crises caused by war, blockade and authoritarian politics have continued to plague the Middle East and Africa. There are many reasons why existing conflicts have proved remarkably difficult to resolve, and why new ones have erupted-these are beyond our scope here. But the principal reason why these wars lead to starvation is that both local commanders and their international backers have been ready to tolerate this abuse.

Yemen is the most egregious case: a war of choice, entered into by Saudi Arabia and the United Arab Emirates, in which starvation is their preferred weapon. The coalition forces have imposed a crippling blockade, have bombed key production, transport, and marketing infrastructure-as well as hospitals and water suppliesand have all-but-destroyed salaried employment and viable economic livelihoods. Meanwhile, western countries including the United States and United Kingdom, have done little to protest this famine crime-the greatest of our generation. They are supplying weapons to the perpetrators and providing political and diplomatic cover for the blockade, overruling the warnings of their own humanitarian specialists. Even emergency relief action plans are being debased to become elements in the war plan. ${ }^{5}$

In these circumstances, aid workers including nutritionists are akin to emergency responders pulling the injured from the rubble, while their own paymasters are still instructing the demolition crews to carry on their devastating business.

The famines or near-famines in north-eastern Nigeria, Somalia, South Sudan and Syria differ in the details of the culprits and their culpability, but in every case, we see starvation inflicted either as a deliberate tool of war, or as the by-product of the pursuit of other political goals in which human lives are seen as disposable. The

${ }^{5}$ Dan Glazebrook (2018), 'The spin machine behind Saudi Arabia's "humanitarian aid plan" for Yemen', Middle East Eye, 2 March, http://www.middleeasteye.net/columns/politicshumanitarian-aid-yemen-646965654 
starvation sieges in Syria attract our outrage in part because their perpetratorsPresident Bashar al Assad and his cabal-are already fully-certified members of the gallery of abusers, responsible for gross war crimes including using chemical weapons. In South Sudan, President Salva Kiir and his commanders have gone from being the darlings of advocacy groups fronted by Hollywood stars, to joining the club of villains.

The extreme hunger in Somalia garners less attention and condemnation. But this year's crisis builds upon the 2011 famine, caused by the vicious intersection of drought, the global food crisis, conflict, and the decision by the U.S. Administration to cut back on food assistance because the PATRIOT Act determined it illegal to provide any form of material support to an entity designated as terrorist-and aid agencies supplying emergency relief to Somalia were unable to guarantee that none of their aid would end up in the hands of the extremist group al-Shabaab or its supporters. It took almost ten months for the U.S. government to decide that it would permit a 'humanitarian workaround' of this provision, and that delay contributed to the 255,000 excess deaths in that famine. ${ }^{6}$

In every case of mass starvation today, what we see is a political culprit who acts with a well-founded sense of impunity, either to inflict intense hunger or to fail to stop it when it is within their power to do so. All are confident that they will not be called to account for their acts. And indeed, starvation is nowhere identified in an unequivocal headline manner as a crime against humanity. In the post-World War Two Nuremberg trials, the Nazi leaders were not prosecuted for mass starvation, in part because the Allies were themselves responsible for comparable acts during the war. Since 1945, the Geneva Conventions have been strengthened and the Rome Statute for the International Criminal Court contains tougher provisions-but in every instance, the prohibition on starvation is either hedged with get-out clauses such as military necessity or hidden within other crimes such as extermination. And no-one yet has been convicted of the crime of mass starvation.

Nutritionists and public health specialists are not lawyers, let alone prosecutors. The tasks of defining famine crimes, compiling evidence and argument, and bringing cases to court, falls upon others. Indeed, the work of practical humanitarian action in a war zone would be rendered more difficult if there were parallel efforts to compile dossiers of evidence of starvation crimes. But the vocation of nutrition does

6 Maxwell, D. and Majid, N. (2016) Famine in Somalia: Competing Imperatives, Collective Failures, 2011-12, London: Hurst. 
not allow for indifference in the face of violations such as those that cause mass starvation. Nutritionists' voices should be heard.

Criminalizing starvation and prosecuting its perpetrators is not an end in itself. Rather these are steps towards a larger goal: stopping famine by outlawing it. Law is a tool for social justice.

Imagine if, during the debates within the Obama Administration in early 2011 over Somalia, the lawyers tasked with enforcing the PATRIOT Act had been challenged by other lawyers citing the principle that starvation is a crime-might the lives of hundreds of thousands of Somali children have been saved? Imagine if there were such a legal opinion on the Saudi-Emirati blockade of Yemen today-might it oblige governments in London and Washington DC to change their policies?

Achieving such a goal demands public pressure. And the outrage certainly existsthough it is not well focused. At a time in which progressive values are under assault, the prohibition of mass starvation might well be a cause on which people of all political colours can agree. There is no moral code, no religious faith, that can permit such acts visited on the poorest, most defenceless people, principally children.

Anti-aid campaigns, such as that of Britain's Daily Express, are not only ethically retrograde but also wilfully ignorant of history 7 : are the organisers of the petition unaware of the social costs and political perils of famine that strikes anywhere in a globalized world? Do these xenophobes not recall that the principal demographic impact of every famine since Ireland in the 1840 s is mass migration?

At this juncture, humanitarians should come together to defend what has been achieved over the last generation. This, I submit, is best done by setting the agenda of prohibiting famine.

Our ultimate goal should be to render mass starvation so morally toxic, that it is universally publicly vilified. A campaign should aim to make mass starvation unthinkable, such that political and military leaders in a position to inflict it or fail to prevent it, will unhesitatingly ensure that it does not occur, and the public will

\footnotetext{
7 Daily Express (2018), 'Foreign aid madness: The massive support for our crusade,' February 8, https://www.express.co.uk/comment/expresscomment/916644/Foreign-aid\acob-Rees-Mogg-petition-Express-Comment
} 
World Nutrition 2018;(9)1

demand this of them. In such circumstances, nutritionists and public health

practitioners may again find that history is on their side, and the conquest of famine is again within our grasp. 